\title{
ENERGY BALANCE IN IRRIGATED WHEAT IN THE CERRADOS REGION OF CENTRAL BRAZIL
}

\author{
A. LUCHIARI JR'; S.J. RIHA'; R.L. GOMIDE' \\ 'Cerrados Agricultural Center EMBRAPACPAC, Planaltina, DF, Brazil \\ ${ }^{2}$ Agronomy Dept, Comell University, Ithaca, NY, USA.
}

\begin{abstract}
To evaluate the water requirements for imigated wheat, a micrometeorological study was conducted during the dry seasons of 1982 and 1983 at the Cerrodos Agxicultural Research Center, Brailla-DF, Brvill. The crop was irrigated when the soll water potential at $5 \mathrm{~cm}$ reached -60 to $-70 \mathrm{~J} / \mathrm{rg}$. Bowen ratio measurements were made on an hourty bails during the entire crop sesson. Total amount of water evapotramopired during the crop cycle and the eners balance terms varied year to year due to regional advection; In 1982, a less advective year, the total amount of water evapotranspired was $345 \mathrm{~mm}$, wh approximately $80 \%$ of the net radiation disdpated as latent heat, $13 \%$ as a sensible heat and 7\% as soll heat after the crop obtained a Leaf Area Index (LAD) of 1.5. In 1983, when advection was greater than 1982, total water evapotranspired increased to $385 \mathrm{~mm}$. The partitioning of energy was stmilar to 1982 during periods of little or no advection. However, during pertods of intense advection, latent heat was greater in net radintion partitioning. Although regional advection increased the water wed by the crop, irrigation scheduling based on soil tensiometers was considered adequate and eficient due to the low values of the Bowen ratio obtained.

Key Words: enerey balance, irrigated wheat, cerrado
\end{abstract}

\section{BALANÇO ENERGETICO EM TRIGO IRRIGADO NA REGIÃO DOS CERRADOS DO BRASIL CENIRAL}

RESUMO: Um extudo micrometeorolojico para avaliar a demanda hidrica do trigo irrigado fol condadido nas estapíes secus de 1982 e 1983 no Centro de Pesquila Agricola dos Cerrados, Braslia-DF, Brasil A cultura foi Irrigada quando o potencial de f́gua no 2010 a $5 \mathrm{~cm}$ athigiu -60 a $-70 \mathrm{~J} / \mathrm{kg}$. Durnnte todo o ciclo da cultura medidas da ravilo de Bowen foram fettas numa base horfiria A quantidade total de ifwa evapotranopirada durante todo ciclo da culturn e o balanco energético variaram entre os anos devido ladveçilo rejoenal; em 1982, um ano menos advectivo, a quantidade total de tapa evapotranapirada fol de $345 \mathrm{~mm}$, sendo $80 \%$ da radiagso liquida diasipada como calor latente, $13 \%$ como calor sensivel e $7 \%$ como calor do 2010 após a cultura ter atingido um Indice de Area Foliar (IAF) de 1.5. Em 1983, quando a advecfto fol maior que em 1982, a quantidade total de dgua evapotranspirada aumentou para $385 \mathrm{~mm}$. A partighto de energin fol similar à 1982 durante periodos de pouca ou nenhuma adveçăo. Entretanto durante periodos de intensa adveccio, o calor latente representou a mafor parte da radiagilo líguida.

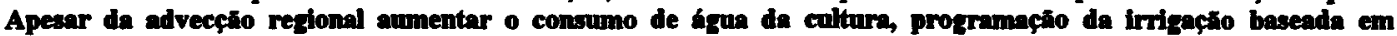
tensiometros fol conalderada adequada e eficiente devido aos baixos valores da ravio de Bowen obtidos.

Descrttores: balanço de energia, trigo irrigado, cerrado

\section{INTRODUCTION}

Land under irrigation has been rapidly increasing in the Cerrados Region of Brazil as a consequence of government incentives to increase the production of irrigated wheat during the dry season and to stabilize the production of other crops during the rainy season. Preliminary estimates indicate that a maximum of $10 \%$ of the total Cerrados Region ( 0.18 million square kilometers) could be irrigated with superficial water and less than $10 \%$ could be irrigated with groundwater (Pruntel 1975, Luchiari Jr. et al. 1981). Limited water resources, in conjuction with high soil infiltration rates and lack of agrometeorological information, have alerted researchers, planners and irrigation agencies of the need for greater understanding of the magnitude and variability in crop water requirements of this region.

The objective of this study was to determine magnitude and variation in wheat water requirements on a daily, seasonal and annual basis and identify factors underlying this variation. The approach used was to determine the energy balance for a field of irrigated wheat on an hourly basis over the entire crop season for two years. Plant growth and phenological 
parameters were also measured periodically during the growing seasons. The Bowen ratio method was employed to measure evapotranspiration because it is valid for conditions of non-neutral stability (Huband \& Monteith, 1986), it is widely used as a convenient standard against which other techniques have been compared (Sharma, 1983, Huband \& Monteith, 1986, Luchiari Jr. et al. 1987), and has proven to be accurate when used over homogeneous agricultural crop communities in the Cerrados area (Horie \& Luchiari Jr., 1981).

\section{MATERIAL AND METHODS}

Experiments were conducted during the dry seasons of 1982 and 1983 in a sprinkler irrigated wheat field at the Centro de Pesquisa Agropecuária dos Cerrados in Brasilia-DF, Brazil. The center is located $15^{\circ} 35^{\prime} \mathrm{S}$ latitude and $27^{\circ}$ $42^{\prime} \mathrm{W}$ longitude and is at an altitude of $1000 \mathrm{~m}$.

The soil of the experimental field was a Dark Red Latosol (Brazilian Classification) or a Typic Haplustox (U.S. Classification) with a $2 \%$ slope in the SW-NE direction. The size of the experimental field differed for the 2 years. During 1982, it was a 1 ha, rectangular plot, in which sensors were mounted to give a minimum fetch of $75 \mathrm{~m}$ in the SE and NE directions and $25 \mathrm{~m}$ in the $W$ direction. During 1983, the experimental area was augmented to $4 \mathrm{ha}$, with a minimum fetch of $100 \mathrm{~m}$ in all directions and $250 \mathrm{~m}$ in the predominant wind direction (SE-NE). The area was planted with a low stature $(80 \mathrm{~cm}$ maximum height), Mexican wheat (Triticum aestivum (L), 'Anahuac') on June 6, 1982, and on June 16, 1983. Rows were oriented SE-NW, $17 \mathrm{~cm}$ apart and planted with 82 seeds per linear meter. Irrigation was controlled with 4 sets of tensiometers installed at various depths (to a maximum of $1 \mathrm{~m}$ ) in the soil profile. Irrigation water was applied in amounts sufficient to bring the whole soil profile $(0$ to $1 \mathrm{~m})$ to a water potential of $-10 \mathrm{~J} / \mathrm{kg}$ whenever the average (4 sampling sites) soil water potential at the $5 \mathrm{~cm}$ layer reached -60 to $-70 \mathrm{~J} / \mathrm{kg}$.

Measurements in both years started the day following planting and terminated when the crop was harvested. The harvest day was the agronomic harvest point (seed moisture content of $14 \%$ ), not the date of physiological maturation of the crop. Leaf Area Index (LAI) was measured at regular intervals (7 days) beginning at the germination stage. Four samples of plant material each encompassing $0.5 \mathrm{~m}$ of row were taken at random over the field. LAI was then measured using an optical stationary leaf area meter. Crop phenology was observed daily and recorded according to the phenological scale of Feeks (Large, 1954).

Evapotranspiration rates were measured using the Bowen Ratio method. Wet and dry bulb temperatures were measured at two heights (10 and $170 \mathrm{~cm}$ ) above the canopy. Shielded and ventilated platinum resistance thermometers were used (Chino, model 111). Net radiation was measured at two meters above the canopy using a net radiometer (Eko, model H211). Reflected short wave solar radiation was measured at the same mast and height as the net radiation and incoming solar radiation was measured at the agrometeorological station adjacent to the wheat field, in to both cases using pyranometers (Eko, Neo Type). Soil heat flux density was measured at a depth of $3 \mathrm{~cm}$ with three soil heat flux plates (Eko) placed at three different locations in order to obtain average values. All sensors were carefully calibrated prior to field installation. Dry and wet bulb thermometers were adjusted in order to give temperature differences of $0.2^{\circ} \mathrm{C}$. After field installation, the sensors were constantly monitored and periodically checked in order to prevent any systematic error during the period of measurements. The output from these sensors was recorded during the entire crop season using electronic analog chart recorders (Yookogawa Corporation). Values were then averaged on an hourly basis in order to calculate evapotranspiration rates as well as the energy balance components.

\section{RESULTS AND DISCUSSION}

Daily variation of the energy balance components: Daily values (07:30 am. to $16: 30$ pm) of energy fluxes calculated from the integration of hourly averages are presented for the entire crop cycle in Figures 1 and 2. The convention used here is that the fluxes are negative when towards the surface and vice-versa, except for net radiation which is positive when toward the surface. The values are expressed as ratios of stored (G), sensible (H), or latent heat (LE) to net radiation (RN). All 3 of these ratios 
vary considerably during the crop growth stages of establishment and tillering (TABLE 1), which last until about 25 days after planting. At this point an LAI of approximately 1.5 is achieved (Figure 3) At this LAI, approximately $95 \%$ of the incoming radiation is theoretically intercepted by the canopy (Campbell, 1977). After this, variation in these ratios decreases. This type of variability in energy fluxes was expected, since at early stages of crop growth, more energy reaches the soil surface. Immediately following irrigation, energy is dissipated primarily as latent heat. However, as the soil dries, latent heat loss rapidly decreases, while soil heat and sensible heat flux increase. For example, changes in the energy balance terms can be observed during a drying cycle from 3 to 12 days after planting in 1982 (Figure 1). The crop was irrigated at night on day
3. The next day $H / R n$ averaged $0.18, G / R n$ averaged 0.07 , and $\mathrm{LE} / \mathrm{Rn}$ averaged 0.75 . However, as the soil surface dries, LE/Rn declines in 3 days to about 0.2 . In the same time period, $H / R n$ increases to about 0.65 , while $G / R n$ increases to 0.15 . These ratios fluctuate slightly around these values until the next irrigation event. The pattern after the next irrigation event is not as extreme due to greater canopy cover (Figure3) and a shorter irrigation interval. The Haplustox soil used in this study quickly forms a surface layer of dry soil which acts as a barrier to water movement to the surface.Evaporation of stored soil water is then severely limited. However, this has no negative effects on crop germination. On the contrary, it is beneficial in the sense that water is conserved in the germination zone.

TABLE 1 - Growing Degree-days $\left({ }^{\circ} \mathrm{C}\right.$ ) for different phenological stages for wheat (cv 'Anahuac') growing under irrigation. 1985.

\begin{tabular}{lcccc}
\hline \multicolumn{1}{c}{ crop phenological Stage } & \multicolumn{2}{c}{ time (day) } & \multicolumn{2}{c}{$\begin{array}{c}\text { growing degree-days } \\
\text { ( }{ }^{\circ} \text { C.day) }\end{array}$} \\
\cline { 2 - 5 } & 1982 & 1983 & 1982 & 1983 \\
\hline I - Establishment & 09 & 10 & 154 & 154 \\
Ila - Tillering & 16 & 16 & 259 & 260 \\
IIb - Head Development & 18 & 19 & 272 & 300 \\
III - Flowering & 14 & 14 & 206 & 212 \\
IV - Yield Formation & 30 & 32 & 510 & 477 \\
V - Ripening & 11 & 10 & 190 & 207 \\
TOTAL & 98 & 101 & 1591 & 1610 \\
\hline
\end{tabular}

Soil heat flux is the smallest component of the energy budgest and behaves similarly in both years (Figure la and 2a). During the early stages of crop growth (establishment to tillering TABLE 1), 15 to $18 \%$ of net radiation is stored in the soil during the daylight hours. After complete ground cover was established (vegetative and flowering stages TABLE 1), soil heat flux is around $7 \%$. Even though LAI is changing over this period (Figure 3), it will have little effect on the amount of radiation reaching the soil surface. In 1982, soil heat flux increased to about $10 \%$ at the ripening stage. The last irrigation was applied fifteen days before harvesting and this long period without irrigation may have accelerated the decline in canopy cover (Figure 3) resulting in more radiation arriving at the soil surface. In 1983, the last irrigation was applied thirteen days before harvesting, but two rainy days occured five and six days after this event. Therefore, the shift in partitioning of energy between $L E$ and $G$ is not observed.

During the 1982 crop season, H/Rn exhibits large fluctuations $(0.2-0.7)$ at the early stages of the crop growth (Figure 1b). After complete ground cover is established (Figure 3), this ratio varied around 0.1 after irrigation and increased to 0.3 preceeding irrigation (Figure $1 \mathrm{~b}$ ). It assumes a negative value only three times (Figure $1 \mathrm{~b}$ ). The ratio LE/Rn likewise fluctuates greatly at early stages (Figure 1c).

It then averages about 0.8 during the rest of the crop season after irrigation and decreases to 0.6 preceeding irrigation. It assumes values near unity on only 3 days (Figure 1c). 
Although soil heat flux is similar in 1982 and 1983, LE and $H$ behaved differently in 1983 as compared to 1982 . At early stages of crop growth in 1983, $\mathrm{H} / \mathrm{Rn}$ is smaller (approximately 0.25 ) and varied less ( 0.0 to 0.4 ) than in 1982 (Figs. $1 \mathrm{~b}$ and 2b), due to more frequent irrigation before canopy closure made in 1983. During the intermediate stage of crop growth, $\mathrm{H}$ frequently assumes negative values. Also, around 70 days after planting there were several positive values for $H / R n$ that were greater than the previous several weeks. This ratio becomes consistently positive again and similar in behavior to 1982 only after day 85 (Figure 2b). The negative values for sensible heat flux indicate temperature inversions and characterize 1983 as a year with recurring sensible heat advection.
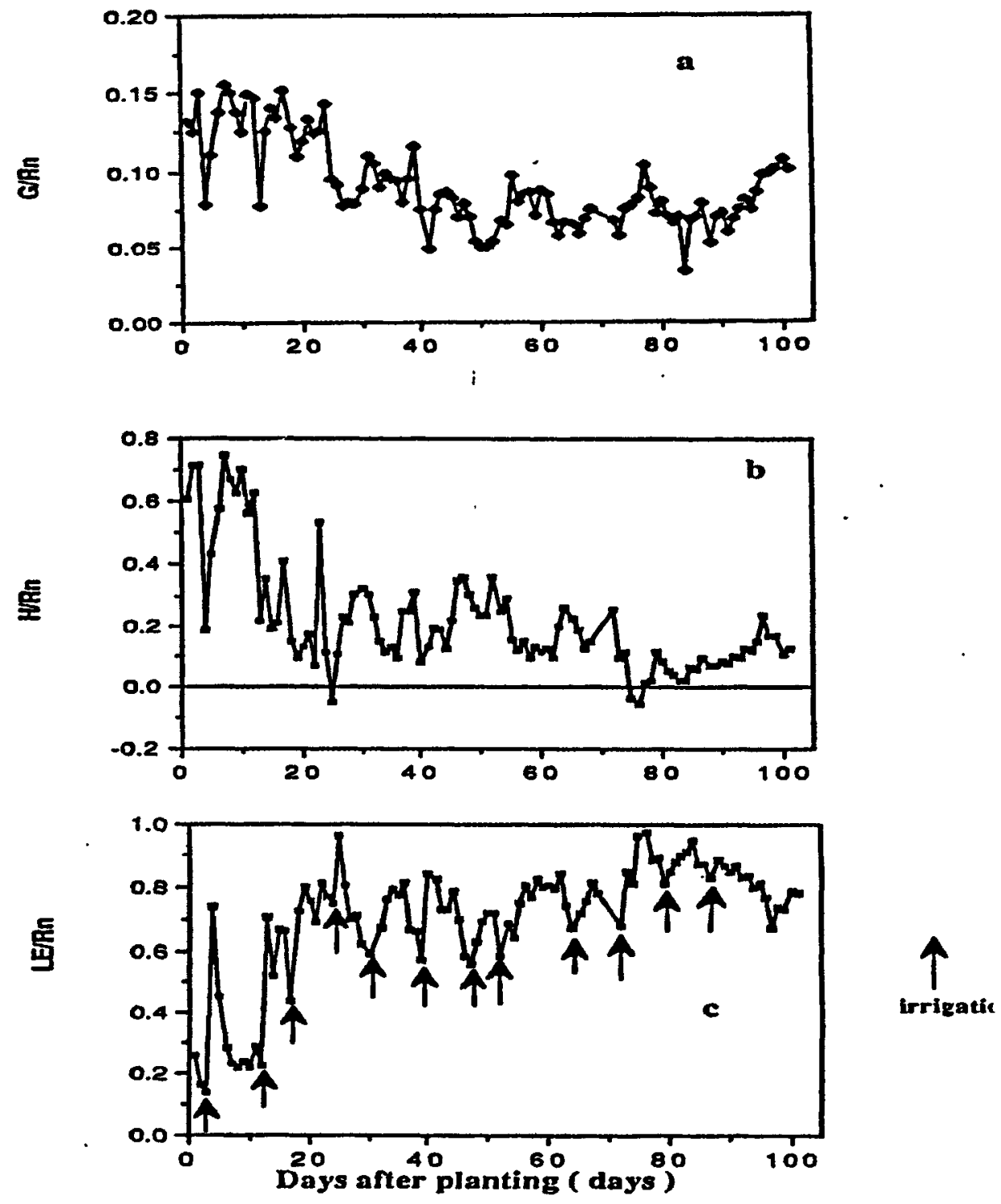

Figure 1 - Daily variation in energy fluxes in 1982 crop season: a) $G / R n$, b) $H / R n$, and c) $L E / R n$. 

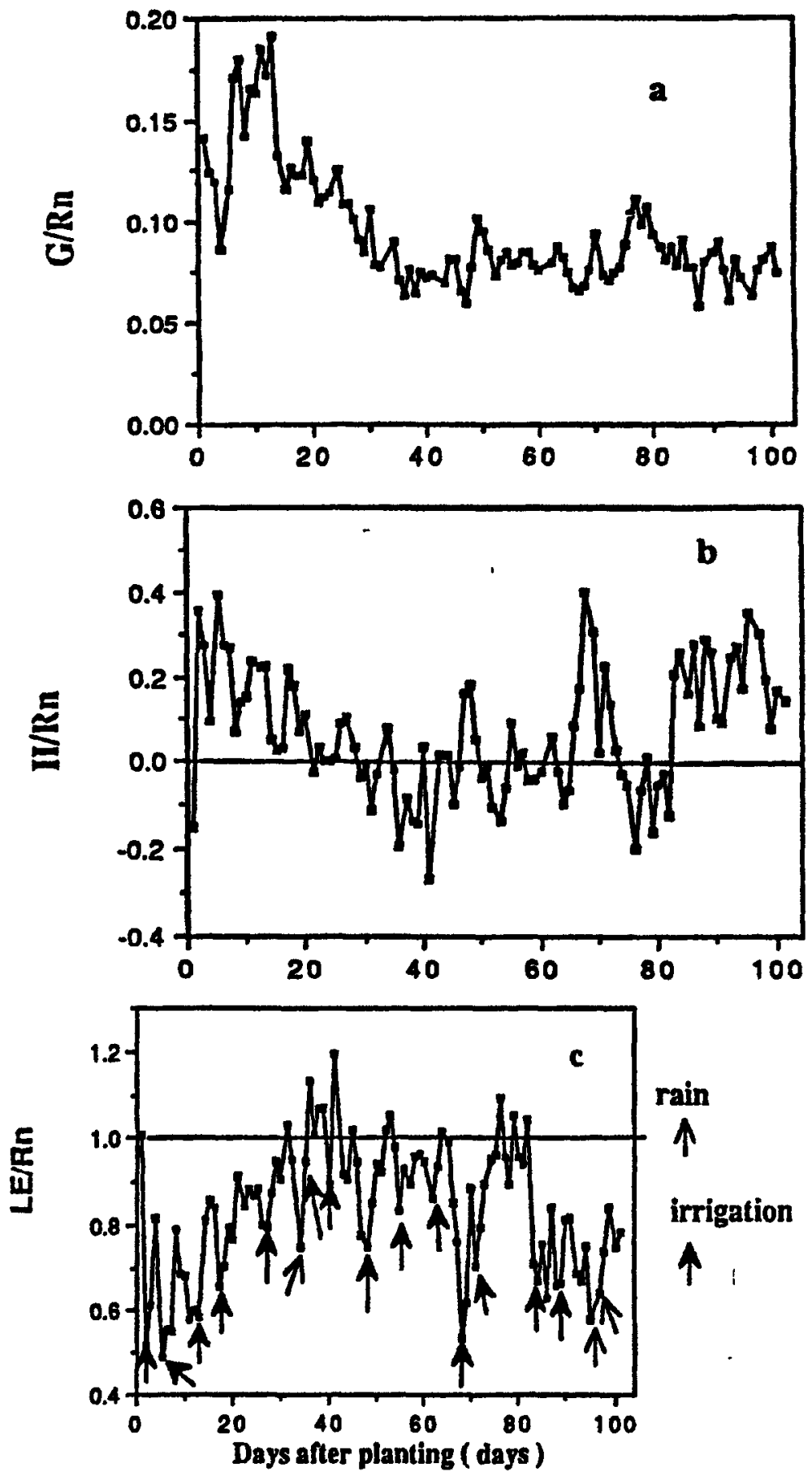

Figure 2 - Daily variation in energy fluxes in 1983 crop season: a) $G / R n$, b) $H / R n$, and c) $\mathrm{LE} / \mathrm{Rn} . \mathrm{LAI}=\exp \left(-1.4154+0.10840 . \mathrm{DAP}-0.001 . \mathrm{DAP}^{2}\right), \mathrm{r}=0.98$ 

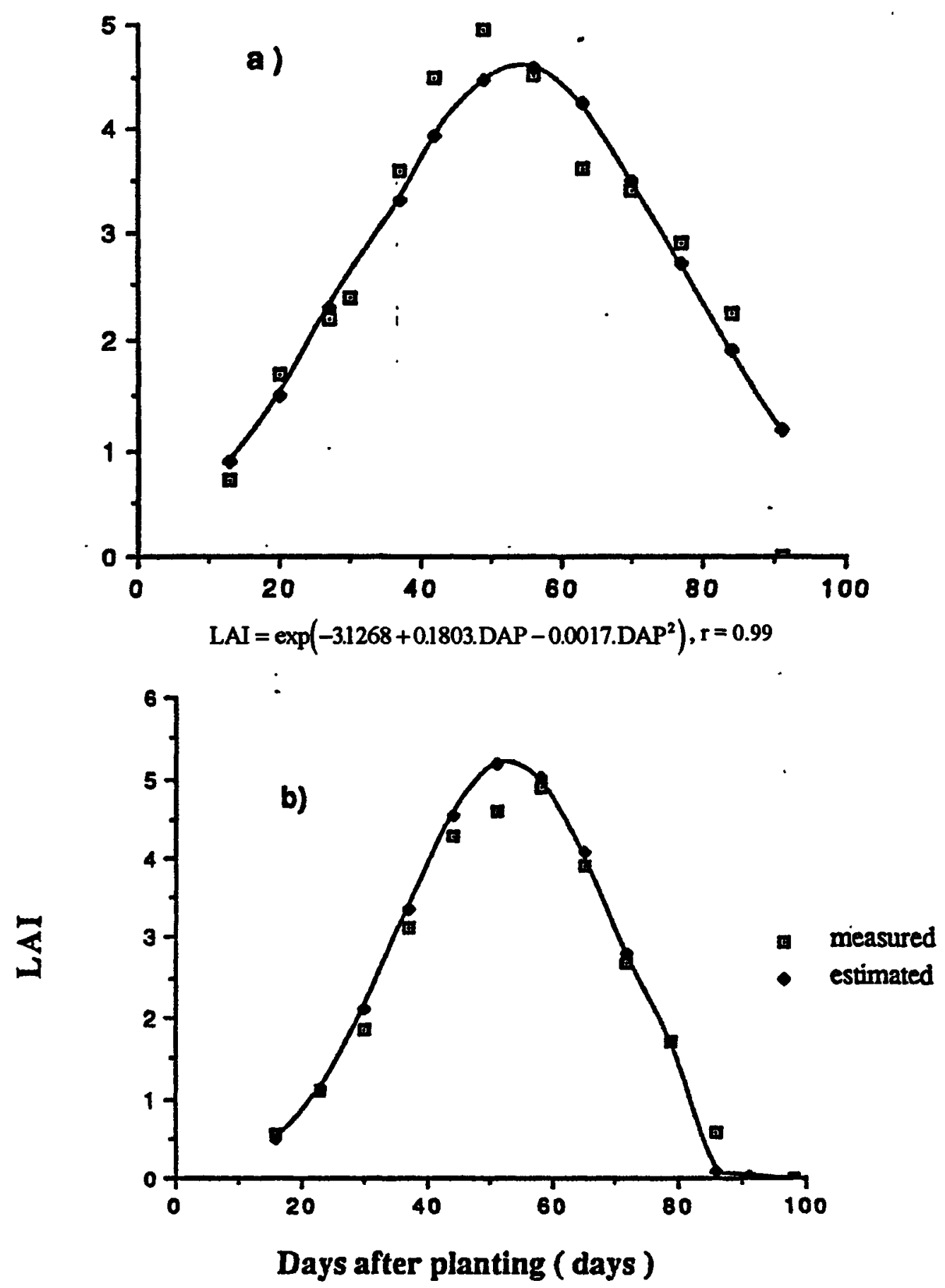

Figure 3 - Variation in green leaf area index (LAD) during the crop seasons of: a) 1982, and b) 1983, and the equations that best fit the data. 
On days when daily $H / R n$ is negative, $L E / R n$ is greater than or equal to 1.0 . On days when daily $\mathrm{H} / \mathrm{Rn}$ is positive, LE/Rn is below 1.0. For example, 65 to 70 days after planting, an increase in $H / R n$ from 0.0 to 0.4 is accompanied by a decrease in LE/Rn from 1.0 to 0.5 . When $\mathrm{H} / \mathrm{Rn}$ decreases 70 to 80 days after planting, LE/Rn increases and obtains values above 1.0 when $\mathrm{H} / \mathrm{Rn}$ is below zero. In this second phase ( 70 to 80 days), the effect of sensible heat advection is even seen in the soil heat flux term which increases to about $10 \%$ during this period (Figure 2a).

Sensible heat advection: The effect of sensible heat advection in increasing latent heat loss has been reported in experiments conducted on a number of irrigated crops grown at many locations throughout the world (Rosenberg, 1983). To better characterize the nature of sensible heat advection, energy fluxes in this study were analyzed on an hourly basis. Two days are discussed in detail. They exhibit 2 different patterns representative of many other days. The first day, August 5, 1983 followed an irrigation event. The soil water potential at $0-10 \mathrm{~cm}$ soil depth was $-10 \mathrm{~J} / \mathrm{kg}$. The second day, August 8 , 1983, was between irrigation events. The soil water potential was $40 \mathrm{~J} / \mathrm{kg}$. Net radiation is similar on both days, reaching a minimun of about $-80 \mathrm{~W} / \mathrm{m}^{2}$ at night and a maximum of about 580 $\mathrm{W} / \mathrm{m}^{2}$ during the day (Figure 4 ). Since the dry season in this region is characteristically clear and sunny, low values of $R n$ during the night (due to strong radiative cooling) and high values during the daytime (due to clear skies) are expected. The soil heat flux is also similar on both days. It is positive (increasing in storage) during the day and negative (decreasing storage) at night $\left(-20 \mathrm{~W} / \mathrm{m}^{2}\right)$, also reflecting the characteristic conditions created by clear, sunny days. Sensible and latent heat fluxes are also similar on both nights. Sensible heat flux $(\mathrm{H})$ is directed from the atmosphere to the surface $\left(-70\right.$ to $\left.-80 \mathrm{~W} / \mathrm{m}^{2}\right)$, while LE is positive, although small (10-20 $\mathrm{W} / \mathrm{m}^{2}$ ). This indicates that evapotranspiration (mainly soil evaporation) occurs at night, driven by the soil heat flux.

Initially we would expect that LE/Rn would be higher on August 5 than on August 8 due to increased soil water availability. However, despite similar values in net radiation, soil heat flux, and night time sensible and latent heat fluxes, total daily evapotranspiration on August 5 was $3.9 \mathrm{~mm}$, in contrast to $5.9 \mathrm{~mm}$ on August 8 . On August 8., the values of LE during the daytime closely followed the values of Rn until midday and became greater than $\mathrm{Rn}$ values during the afternoon. This was caused by advection (negative values of $\mathrm{H}$ ) occurring all day, especially in the afternoon $\left(-100 \mathrm{~W} / \mathrm{m}^{2}\right)$ (Figure 4b). In contrast, on August 5, LE proceeded at rates lower than $\mathrm{Rn}$ during most of the day until late in the afternoon, when values of LE became greater than $\mathrm{Rn}$ (Figure 4a). On this day $\mathrm{H}$ is positive in the morning, reaching a maximum value $\left(100 \mathrm{~W} / \mathrm{m}^{2}\right)$ around 11:00 am. Thereafter values for $\mathrm{H}$ decline and remain close to zero during most of the afternoon. Values for $\mathrm{H}$ become negative later in the afternoon and at the same time LE/Rn becomes greater than one.

The dry season in the Cerrados begins in late April and continues through September, and August is one of the windiest months of the year. The type of advection that occurred on August 5 would be expected, since heat generated from the surrounding dry land coud easily be transported to the irrigated field during the hottest and windiest hours of the day. Forty six days in the 1983 crop season, and 20 days in the 1982 crop season displayed this type of advection. Eighteen days of the 1983 crop season exhibited the type of advection that occured on August 8, in contrast to three days in the 1982 season. The origin of this strong advection is not known. No clear trends were observed in either wind velocity or direction. However, it appears to be a regional, as opposed to local, event.

The total water used by the wheat crop was $345 \mathrm{~mm}$ in 1982 and $385 \mathrm{~mm}$ in 1983. The increase in 1983 is considered due primarily to increased regional advection. Climatic patterns related to this type of advection and their frequency of occurrence in the Cerrados region are not known. However, gaining knowledge in this area will be important for estimating crop water requirements on a regional and long term basis.

Daily variation of the Bowen ratio: In 1982, following large fluctuations before canopy closure, the Bowen ratio (H/LE) ranged from 0.2 to close to zero (Figure 5a). In contrast to 1982 , under the advective conditions of 1983 some values of the Bowen ratio are negative but are otherwise generally close to zero after canopy 
closure (Figure 5b). Given the low Bowen ratios measured during most of both growing seasons, irrigating when the soil water potential reached -60 to $-70 \mathrm{~J} / \mathrm{kg}$ was considered adequate and efficient. Although the Bowen ratio decreased slightly between irrigations, a previous study had indicated that more frequent irrigation did not result in increased crop growth and yield (EMBRAPA/CPAC, 1987).

\section{a) $8 / 5 / 83$.}

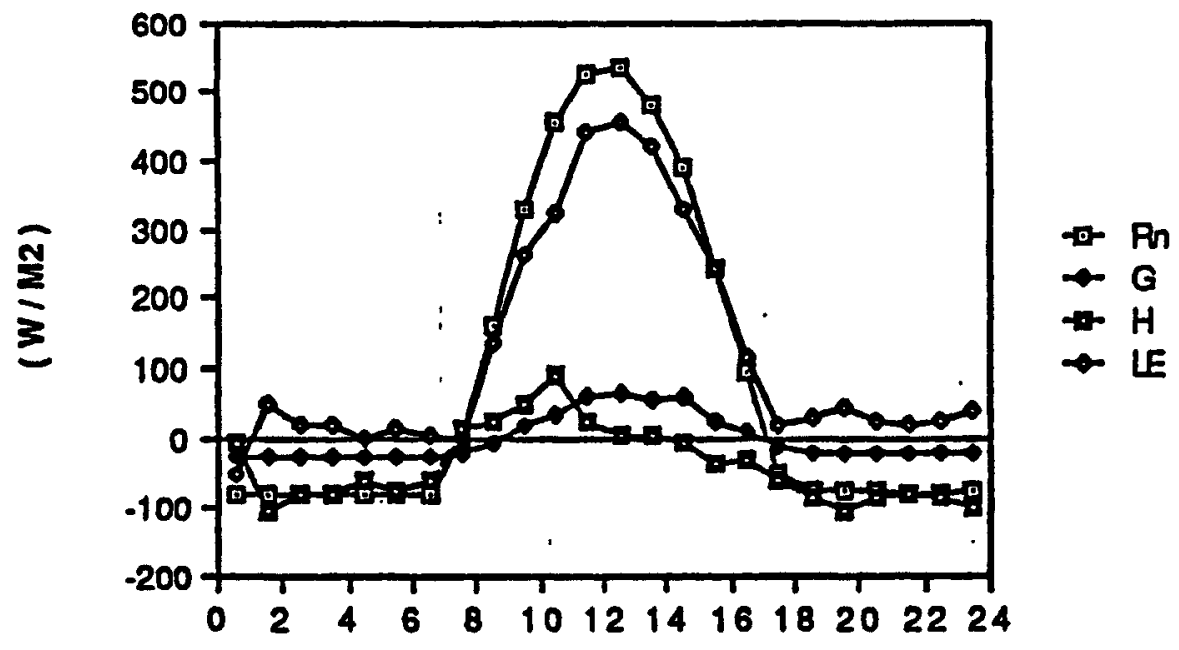

b) $8 / 8 / 83$

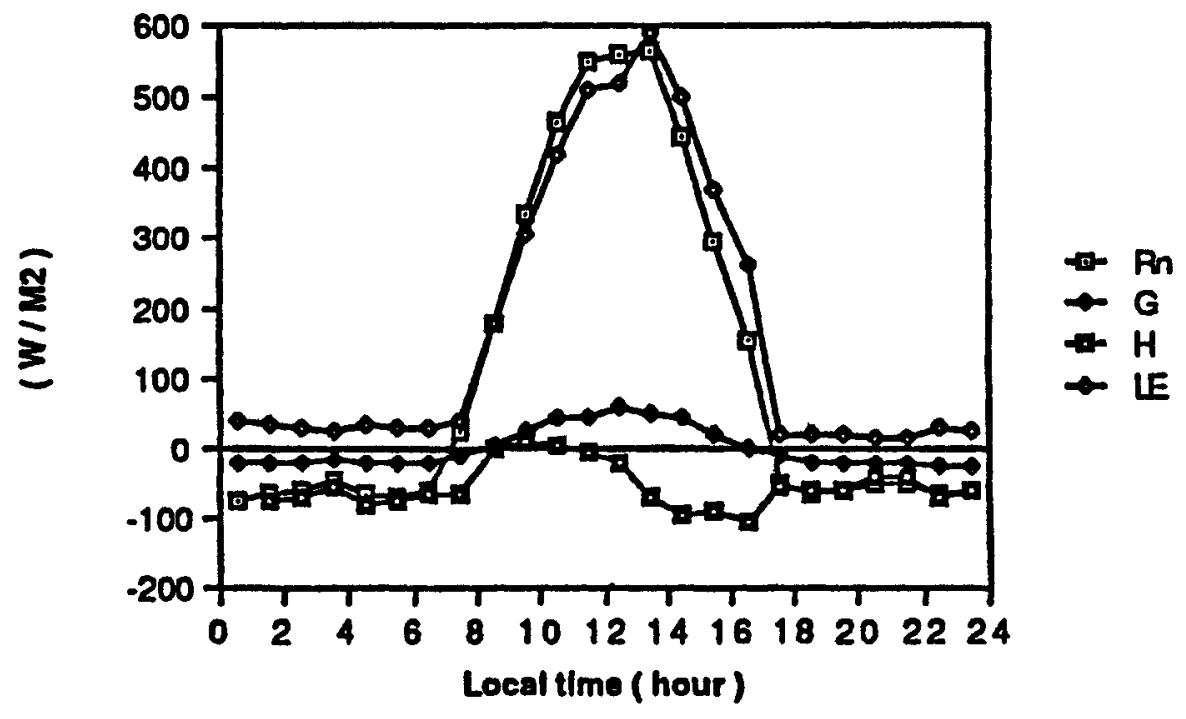

Figure 4 - Daily course of the energy balance terms: net radiation - Rn, stored heat - G, sensible heat - H, and latent heat - LE, under a) moderate (8/5/83) and b) strong (8/8/93) advection. 

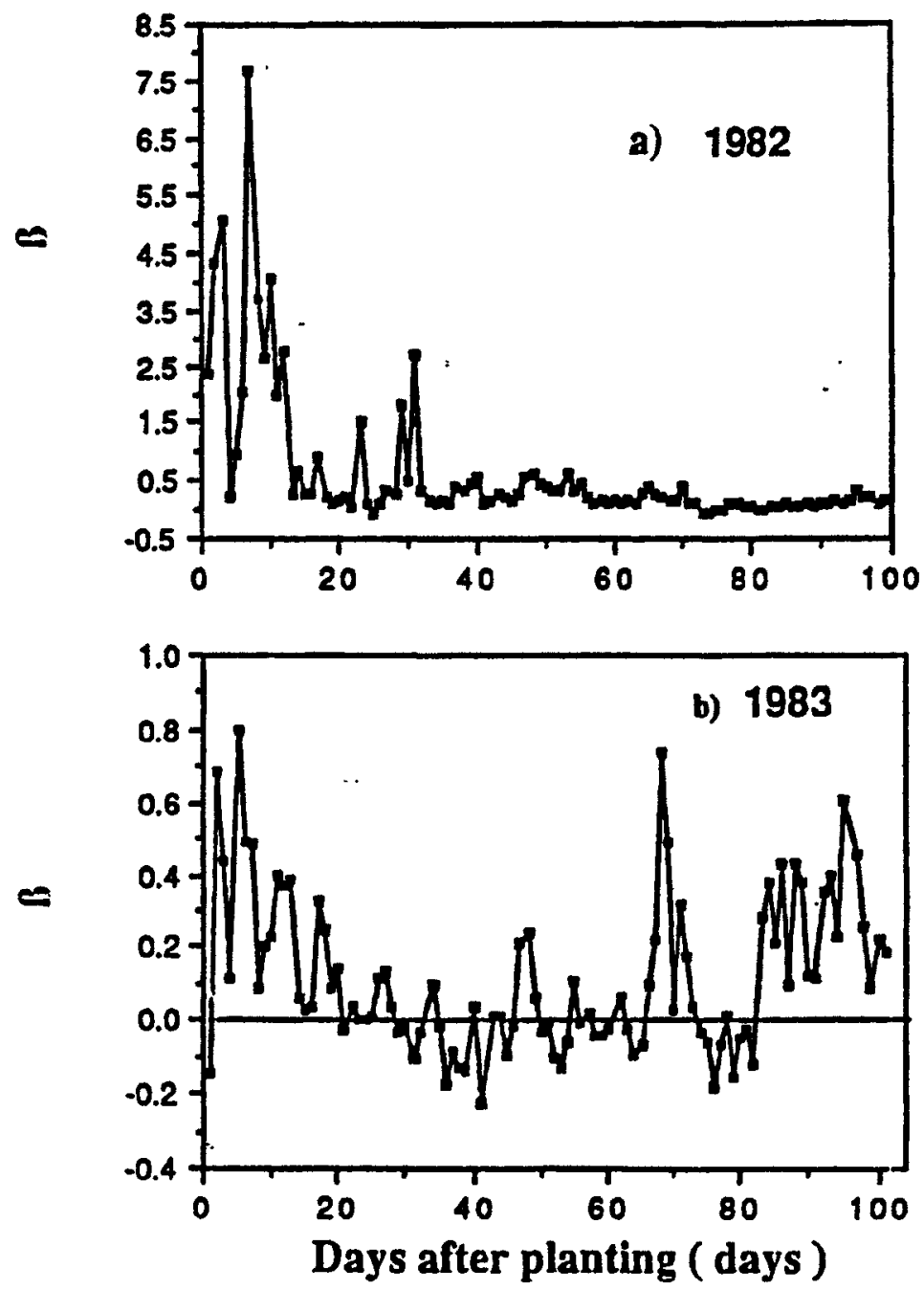

Figure 5 - Daily variation of the Bowen ratio during a) 1982 and b) 1983 crop seasons.

Daily variations in albedo and net radiation $(\mathbf{R n})$ : Variation in the surface albedo (ratio of reflected over incoming radiation in the $0.3-3.0$ $\mu \mathrm{m}$ range) for the crop season of 1982 is shown in Figure 6. Bare soil albedo ranges from about 0.15 for dry soil to 0.12 for wet soil, indicating that the amount of radiation absorbed is not greatly affected by moisture conditions. The surface albedo increases in value early in the season as the green LAI increases (Figure 3a). It then reaches a plateau from 30 to 50 days after plan- ting (dap) with values around 0.26 . After this, the surface albedo decreases, gradually to values around 0.18 until 90 dap, perhaps due to a change in color of the surface, following a decrease in green LAI and increased exposure of the soil surface. At 90 dap to the end of the season, the albedo increases again due to change in color of the surface as the canopy matures (green to golden-yellow), although this is modified by the fact that at this stage of crop development, a greater portion of the soil surface is exposed. 


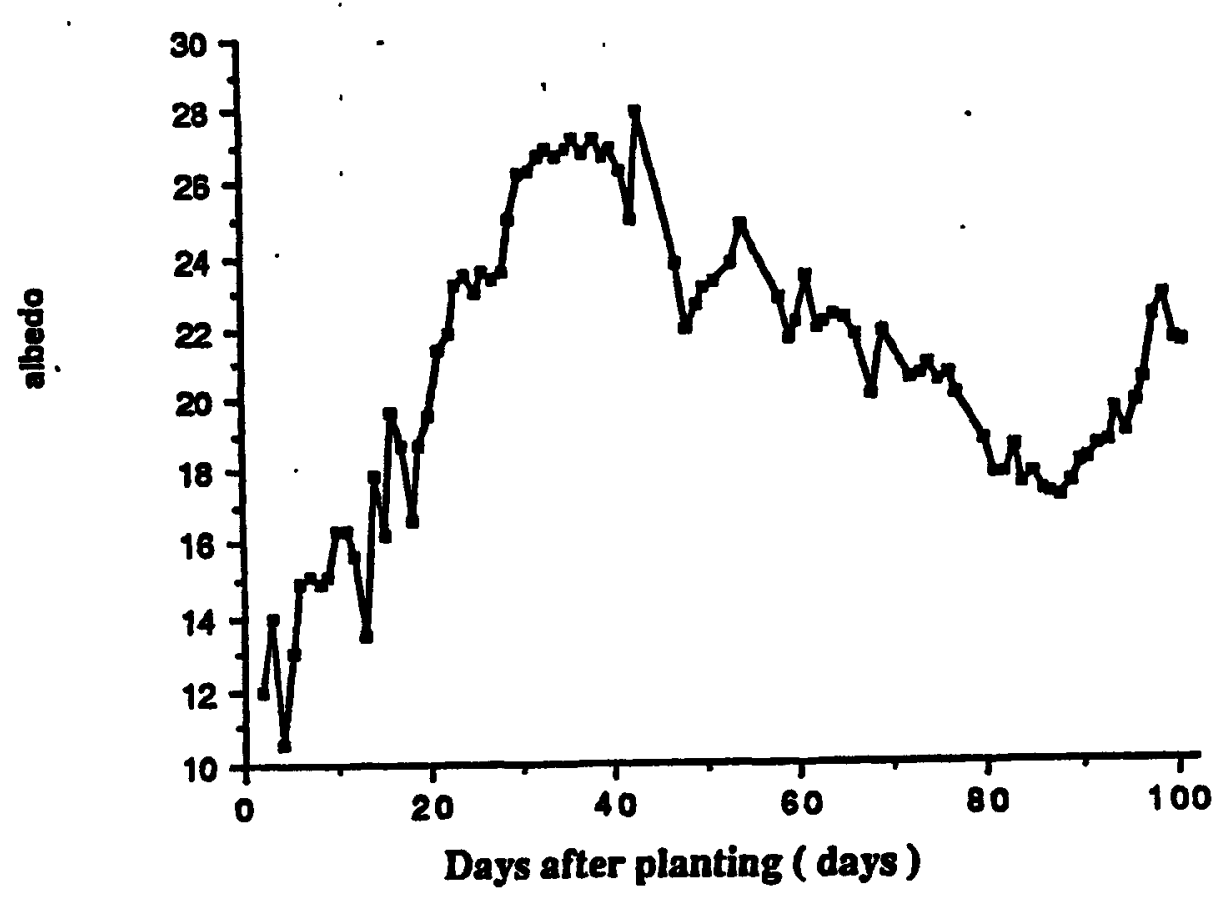

Figure 6 - Variation in surface albedo during the 1982 crop season.

Since the experimetal area is located at a latitude of $15^{\circ} 35^{\prime} \mathrm{S}$, the daily flux of solar radiation varies little throughout the year. Due to clear sky conditions during the dry season, solar radiation ranges from 15 to $18 \mathrm{MJ} / \mathrm{m}^{2}$ day. Consequently, the observed $\mathrm{Rn}$ in both years fluctuated very little, from 8 to $11 \mathrm{MJ} / \mathrm{m}^{2}$ day.

Length of the growing season: The influence of air temperature on phenological development of wheat in this study was evaluated using the growing degree-days (GDD) concept. GDD for each phenological stage was calculated from the following expression:

$$
\mathrm{GDD}_{\mathrm{m}}=\sum_{\mathrm{im}=0}^{m}\left(\frac{\mathrm{T}_{\max _{1}}+\mathrm{T}_{\min _{1}}}{2}-\mathrm{T}_{\mathrm{b}}\right)
$$

where GDD is the accumulated growing degreedays $\left({ }^{\circ} \mathrm{C}\right)$ for a given phenological period from day $=\mathbf{0}$ to day $=\mathrm{m}, \mathrm{T}_{\max }$ is maximum daily air temperature $\left({ }^{\circ} \mathrm{C}\right), \mathrm{T}_{\min }$ is minimum daily air temperature $\left({ }^{\circ} \mathrm{C}\right.$ ) and $\mathrm{t}_{\mathrm{b}}$ is the basal temperature $\left(5^{\circ} \mathrm{C}\right)$. Both the 1982 and 1983 seasons had similar GDD values for the crop growth stages distinguished (TABLE 1). The variation in GDD during stage $1 \mathrm{lb}$ is a consequence of four cloudy days which occurred in 1983. Since at this stage the plant photosynthetic activity is high, the reduction of incoming solar radiation seems to have acted as the main controlling factor and delayed this stage. At stages IV and V the variations are lower than $10 \%$ and are within an acceptable limit of error in recording the phenological stages under field conditions.

The concept of thermal units should work well in predicting wheat development and the length of the growing season for irrigated wheat in the Cerrados Region. In general there is little variation in radiation year to year during the dry season over the entire region (Motta et al. 1975). Temperature tends to decrease south of and to increase north of the Brasilia latitude and to decrease as a function of elevation (Adamoli et al. 1985). Elevation of the wheat producing areas in the Cerrados ranges from 600 to $1200 \mathrm{~m}$. Therefore, the length of the growing season will 
be mainly a function of temperature. Since the length of the growing season will influence the total water requirements and also crop management practices (e. g. side-dressing of nitrogen fertilizer), further testing of the GDD concept in these areas seems justified.

\section{CONCLUSIONS}

In this study, horizontal advection of sensible heat was the most important factor influencing annual variation in crop water requirements in irrigated wheat in the Cerrados Region of Brazil. Total water use by the wheat crop was $345 \mathrm{~mm}$ in 1982 and $385 \mathrm{~mm}$ in 1983. Two types of advection were distinguished, one in which the sensible heat was negative during most of the day (regional scale advection) and another in which sensible heat flux was not negative until afternoon (local scale advection). The increase water use in 1983 was considered mainly due to increased regional advection. It was not possible to identify the origin of regional advection. Therefore, we have no ability currently to predict the likelihood of occurrence of this phenomena. Although regional advection was clearly important in increasing the water used by the crop, the irrigation scheme adopted was considered adequate and efficient even under advective conditions on basis of the low values of the Bowen ratio obtained throughout the study. Variation in the length of the growing season due to differences in air temperature throughout the region may also be expected to affect crop water requirements.

\section{REFERENCES}

ADÁMOLI, J.;. MACEDO, J.; AZEVEDO, L.J.; MADEIRA NETTO, J. Caracterização da região dos Cerrados. p . 33-74, In W. J. Goedert (ed.) Solos dos Cerrados: tecnologias e estratégias de manejo. Nobel, São Paulo, Brazil. 1985.

CAMPBELL, G.S. An introduction to Environmental Biophysics. Spring- Verlag, New York. 1977.
EMBRAPA/CPAC. Relatório técnico do Centro de Pesquisa Agropecuária dos Cerrados 1982/85. Planaltina, DF, Brazil. 1987. 532p.

HORIE, T.; LUCHIARI JR., A Evapotranspiration rates from an irrigated soybean field in Cerrados as measured by energy balance method. P. 149-181. In Japan International Cooperation Agency. Relatório do Projeto da Cooperação em Pesquisa Agrícola nos Cerrados do Brasil. Planaltina, DF, Brazil. EMBRAPA-CPAC/JCA (English). 1981.

HUBAND, N.D.S.; MONTEITH, J.L. Radiative surface temperature and energy balance of a wheat canopy. Part 2: Estimating fluxes of sensible and latent heat. Boundary-Layer Meteorology, v.36, p.107-116, 1986.

LARGE, E.C. Growth stage in cereals. Illustrations of the Feeke's scale. Plant Pathology, v.3, p.128-129, 1954.

LUCHIARI JR., A;. AZEVEDO, L.G.; MANZAN, R.J. Avaliação das disponibilidades de água subterrânea no Distrito Federal e suas possibilidades de uso. P. 636650. In IV Simpósio Brasileiro de Hidrologia e Recursos Hidricos. Fortaleza - Brazil (Portuguese English Abstract). 1981.

LUCHIARI Jr., A; GOMIDE, R. L.; SILVA, E.M.; CARVALHO, L.J.C.B. A drainage lysimeter for actual evapotranspiration measurements. Agron. Abst. p. 14. 1987 Annual Meetings: ASA, CSSA and SSSA. Atlanta, GA 1987.

MOTA, F.S. D.A; BEIRSDORF, M.I.C; ACOSTA, M.J.C. Estimation of solar radiation in Brazil. Agricultural Meteorology, v.18, p.241-254, 1977.

PRUNTEL, J. Water Availability and soil suitability for irrigation water impoundments in the Federal District of Brazil. M. S. thesis. Comell University, Ithaca, NY. 1975.

ROSENBERG, N.J.; BLAD, B.L.; VERMA, S. B. Microclimate: the biological environment. John Wiley \& Sons, Inc., New York, NY. 1983.

SHARMA, M.L. Estimating evapotranpiration. Advances in Irrigation, v.3, p. 213-281, 1983.

Recebido para publicação em 01.04 .97 Aceito para publicação em 10.04 .97 